\title{
An Analysis of Assessment Models Employed by The Indonesian Elementary School Teachers
}

\begin{abstract}
CrossMark
Wayan Maba ${ }^{\mathrm{a}}$; Ida Bagus Nyoman Mantra ${ }^{\mathrm{b}}$;

Article history: Received 10 November 2016; Accepted in revised form 25 March 2017; Approved 27 April 2017; Available online 30 April 2017

Correspondence Author ${ }^{\text {a }}$

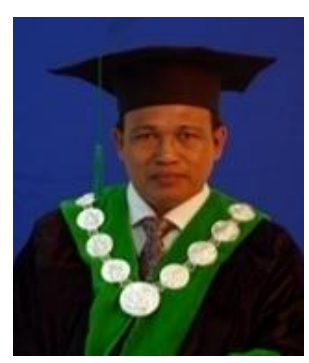

\section{Keywords}

Assessment;

Attitudes;

Elementary school;

Model;

Teachers;

Abstract

The present study was conducted to analyze the assessment models employed by Indonesian elementary school teachers in the context of assessment models as suggested by the curriculum in 2013. The analysis includes the selected assessment models and their implementation in real classroom settings to assess the students' attitudes, knowledge, and skills. This study made use of a qualitative research design in which the data were analyzed by means of deep argumentation and presented descriptively. Data were collected through direct observation and indepth interviews to the selected elementary school teachers. The collected data were analyzed in an analytical manner to obtain the findings. The findings of the present study indicated that primary school teachers employed various models of assessment based on the aspects of attitudes, knowledge, and skills. Assessment of the students' attitude includes observation, self-assessment, peer assessment, and teachers' records. Assessment of the students' knowledge includes a written test, an oral test, and assignment. Assessment of the students' skill includes performance, portfolio and project. Meanwhile, the scores of the students' achievement were analyzed based on the scores of the students' attitude obtained by using the instruments, such as observation blank sheet, Self-assessment, peer assessment, and teacher' records. Self-assessment and peer assessment were also used as a confirmation of the scores for the report card and the teachers' records were mainly used to provide the suggestions for the students' improvement.
\end{abstract}

e-ISSN : 2550-7001, p-ISSN : 2550-701X@ Copyright 2017. The Author. SS Journals Published by Universidad Técnica de Manabí.

This is an open-access article under the CC BY-SA 4.0 license

(https://creativecommons.org/licenses/by-sa/4.0/)

All rights reserved.

\section{Contents}

Abstract

a Mahasaraswati University, Denpasar, Bali, Indonesia

b Mahasaraswati University, Denpasar, Bali, Indonesia 


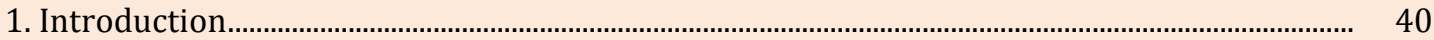

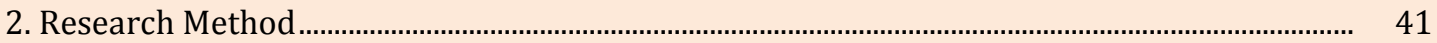

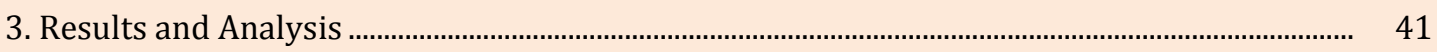

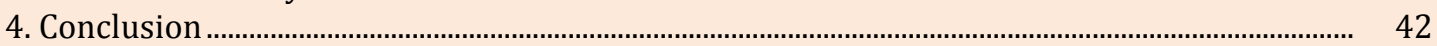

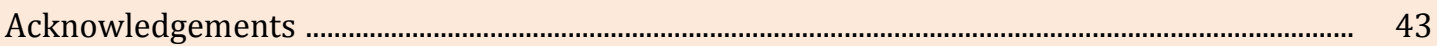

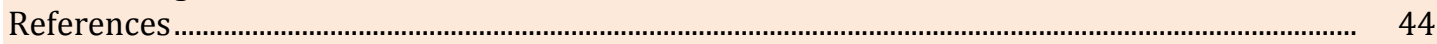

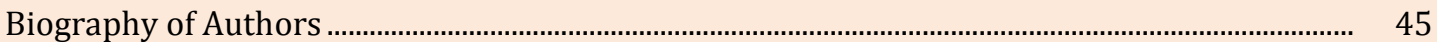

\section{Introduction}

A teaching and learning process mainly consists of three interconnected components such as teaching, learning, and assessment. Assessment is conducted by educators to monitor the process, progress, and improvement of learning outcomes of students on an ongoing basis. Moreover, assessment is an attempt to determine the achievement of educational goals. Measuring the learning outcomes enables teachers to know the success of their students and the result of the assessment becomes feedback for teachers and learners in carrying out the next learning process (Black, Harrison, Lee, Marshall, and William, 2004; Rahman, Babu, and Ashrafuzzaman, 2011.) In the nature of the assessment is implied the purpose of conducting an assessment is to obtain the evidence that may show the level of ability and success of the students in achieving the curricular goals. In addition, it can also be used by teachers and educational supervisors to measure or assess the extent to which the effectiveness of learning experiences, learning activities, and learning methods are being conducted. Thus, it can be said that it is vitally important the role of the assessment is in the teaching and learning process (Box, Skoog, Dabbs, 2015; Newton, 2007; Sri Widiastuti, 2016).

In a broader sense, assessment is a process of acquiring and providing essential information to make an alternative decision on the improvement of teaching and learning practices. Therefore, each assessment activity is a process that deliberately planned to obtain information or data and based on the data and then a decision is made. In relation to learning activities, assessment is a systematic process to determine decisions to what extent learning objectives have been achieved by learners (Nespor, 1987; Newton, 2007; Shepard, 2005.). Assessment can be in the form of formative and summative assessment. Formative assessment is conducted to enhance the teaching-learning practices, meanwhile, summative assessment is intended to measure the students' learning achievement in a specified period of time (Shepard, 2005; McMillan, Venable, and Varier, 2013; Sri Widiastuti, 2016).

Additionally, the function of the assessment can be categorized into four functions, namely (a) to know the progress and development and success of learners after experiencing the learning activities for a certain period of time. The results of this assessment can then be used to improve the way the students learn (formative function), and to determine the class improvement or to determine whether or not a learner passes from a particular educational curricular (summative function); (b) to know the success rate of the learning program (Taras, 2005; Sri Widiastuti, 2016). Learning as a system consists of several components that are related to each other. The components include the objectives, learning materials, methods and activities of teaching and learning, learning media and resources, and assessment procedures and instruments; (c) for guidance and counseling, especially to find out what matters a learner or group of learners require in remedial services, as a basis for dealing with specific cases among learners; and as a reference in serving the needs of learners in the context of career guidance; (d) for the development and improvement of the school curriculum. This is related to the activities of teachers in conducting evaluation activities in order to assess the success of learners learn and assess the learning program, which means also assess the achievement of competencies set in the curriculum (McMillan, Venable, and Varier, 2013, Sri Widiastuti, 2017).

Starting in the academic year 2013, the Government has implemented a new curriculum called the 2013 Curriculum (Mulyasa, 2013). According to this Curriculum, the assessment processes and outcomes of learning are important components of the learning activities in addition to the other components. The curriculum is a set of plans and arrangements regarding the objectives, content and learning materials as well as the means used to guide the implementation of learning activities to 
achieve specific educational goals. Consequently, the learning process is an effort to achieve the Basic Competencies formulated in the curriculum (Nespor, 1987; Sri Widiastuti, 2017).

Meanwhile, assessment activities are conducted to measure and assess the level of achievement of Basic Competence. Assessment is also used to determine the strengths and weaknesses in the learning process, so it can be used as a basis for decision-making and improving the learning process that has been done. Therefore, a good curriculum and the correct learning process should be supported by a good, planned and sustainable assessment system (Newton, 2007; Rahman, Babu, and Ashrafuzzaman, 2011.). Assessment is a series of activities to obtain, analyze, and interpret data about the learning process and the learning outcomes which are administered in a systematic and sustainable manner in order to get meaningful information for the decision-making practices. In regard to the 2013 curriculum, activity-based learning, and the assessment process are both essentially important to be effectively conducted by the teachers.

\section{Research Method}

A qualitative approach was used to analyze the data of the study. In this study, the data about the teachers' the assessment models used in the 2013 curriculum was explained descriptively. This type of research was employed because it described the teachers' the assessment process conducted by the teachers in the 2013 curriculum. This research was conducted in several elementary schools. The data were collected by doing classroom observations and in-depth interviews to the elementary school teachers. The participants of the study were chosen by doing random sampling technique in order to get various data regarding the teachers' assessment models used in 2013 curriculum implementation. The data were collected by conducting in-depth interviews, in relax situation to the teachers to get data related to the teachers' assessment models in 2013 curriculum. The interview guide was the instrument used to collect data related to teachers' assessment models. The data were also collected by doing direct observation. In this study, researchers conducted observations on assessment activities during the teaching and learning process in the classroom. Observations were conducted to find out the implementation of the 2013 curriculum assessment conducted by teachers in the classroom. The data obtained from interviews were firstly transcribed and then interpreted. The transcription of the interview and observation were coded into categories. Then the categorized data were analyzed and described argumentatively.

\section{Results and Analysis}

In principle, effective classroom assessment should be intensively done by teachers and students. This needs to be done together because only the teachers' concern is to know the highest level of student's achievement in learning. Meanwhile, students need to know how to improve their academic achievement based on their ability. In 2013 curriculum implementation, teachers have to carry out classroom assessment, such as portfolio, product, project, performance, and written test. After conducting a series assessment as mentioned above, then the parents are informed by giving written reports descriptively which focus on the competencies that have been achieved by the students.

The assessment processes were conducted by the teachers in both formal and informal held in a pleasant atmosphere, making it possible students demonstrate what they were understood and capable of doing. Students were not given chances to compare their answers with the students to ensure that their own work would reflect their own ability. Based on the analysis of data that teachers, there were several types of assessment models to gather the information about the students' progress to assess the students' attitudes, knowledge, and skills. The assessment models used by the teachers can be classified as the following. Assessment of attitude aspect was obtained by using instruments: (1) observation; (2) self-assessment; (3) peer assessment and (4) journal of teacher's records. To assess the students' skill and learning performance, the teachers employed several types of assessment, such as (1) performance, (3) projects and products, (4) portfolio, and (5) practice.

The assessment carried out by the teachers, which reflects the achievement of basic competence in core competence of attitudes and core competence of psychomotor were measured by using the reference criterion and scoring rubrics to properly figure out the students' ability. The remedial program as a form of follow up actions were planned and conducted accordingly. The remedial

Maba, W., \& Mantra, I. B. N. (2017). An analysis of assessment models employed by the Indonesian elementary school teachers. International Journal of Social Sciences and Humanities, 1(1), 39-45. https://doi.org/10.29332/ijssh.v1n1.38 
programs were conducted as attempt to enrich the students' achievement of higher learning standards. The enactment of the curriculum in 2013 has brought consequences of improvements and changes in assessment system. To collect information about the students' learning progress, a variety of assessment models, however, in principle, there are several models that were used by the teachers namely performance assessment, attitude assessment, written assessment, project assessment, product assessment, portfolio assessment, and self-assessment.

Performance assessment which was conducted by the teachers was used as an alternative. It is a form of measuring the students' ability that requires students to perform a task rather than select an answer a series of written tests. The students are asked to explain historical events, generate scientific hypotheses, solve problems, conduct a conversation, or conduct research on an assigned topic. Teachers then judge the quality of the student's work based on an agreed-upon set of criteria. This form of assessment is most often used by the teachers to directly assess the students' ability to figure out their actual ability or achievement.

In 2013 curriculum, teachers are required to conduct the assessment of attitude to find out the students' attitude during the learning process. The assessment was conducted by utilizing the observation sheet to note down changing attitude and their reaction towards the process of learning experiences. The students' attitude was considered to be important to note down because the students' attitude in learning could also reflect their social attitude in their real life. Therefore it is essential for the teachers to know all the students' changing attitudes in learning. Writing assessment was conducted by the teachers to gather the information concerning the students' performance or potential through a writing task. There are many several different kinds of assessments conducted by the teachers both in the form of subjective and objective tests.

Project assessment was conducted to allow the students to work together to show what they have learned because most students work on many solo activities throughout the day, giving them a time to collaborate are likely be a welcome change of pace for the students. Project assessment is key to keeping the students productive. Understanding which students have the necessary skills to perform their work correctly can help the teachers make important decisions. Students who do not measure up to the minimum required standards may need to be encouraged to study more actively. Those who exceed standards may need to be promoted or maximize their ability. Meanwhile, product assessment was conducted to ensure the students build up their competence to create something. The ability of the students to make products is important to be developed in order that they can survive in the modern society.

Portfolio assessment was conducted along with the performance criteria that are clearly articulated. This means that rubrics, checklists, rating scales, self-assessment, self-reflection, and teachers' comments are part of the portfolio, in addition to examples of the learner's best work. An assessment portfolio is an organized collection of the students' work that demonstrates their skill and achievement and progresses over a period of time. The portfolio is an effective way of keeping up the students' real progress in learning. Therefore the teachers have mostly used this type of assessment to record the students' achievement in a certain period of time.

Portfolios can score in many different ways, but each item that is included is usually individually assessed using specific criteria. A holistic scoring process may be used to establish a final assessment of the overall reflection of the students' work. It is common for the teachers to work together to establish consensus regarding standards for students' demonstrations of skills. Meanwhile, selfassessment is a valuable tool as it gives students the ability to really consider their learning and equally as importantly, share that understanding with the teacher. Once we understand what students know and can do, both demonstrated in the work and their ideas about the work, we can adjust instruction and/or class pacing as needed. The better-tailored class time and assessments can be then carried out to then in the upcoming teaching session. Self-assessment can be a rich way to extend the depth of independent learning and also aid in informing the teacher about valuable data around growth and understanding.

\section{Conclusion}

Assessment is an activity of gathering information about the students' processes and students' learning outcomes conducted by the teacher. The assessment includes knowledge, attitude, and skill. 
The assessment models employed by the teachers are mainly in the forms of (1) observation; (2) Selfassessment; (3) peer assessment and (4) journal of teacher records. The students' scores were written on the report card, self-assessment, and peer assessment sheets. Meanwhile, the suggestion for the students' skill and achievement were mainly taken based on the notes presented in the teachers' journals.

\section{Acknowledgement}

The authors would like to express their profound gratitude to all educators, teachers, and researchers for their help in conducting and writing this study. Deep sincere gratitude also goes to the government authority of Education in Bali Province for the opportunity to study their education system. Special thanks are dedicated to all friends for their support, their contribution, and their valuable input during the writing of this paper. Sincere gratitude also goes to the editors who have reviewed and approved this article to be published.

\section{References}

Adetunji, A. T., Adetunji, A. V., Adeleke, E. O., \& Madubuike, S. C. (2017). Deregulation: The Effect of Market-led Approach to Nigerian Universities Management. International Journal of Social Sciences and Humanities (IJSSH), 1(1), 1-8.

Amerta, I. M. S. (2017). The Role of Tourism Stakeholders at Jasri Tourism Village Development, Karangasem Regency. International Journal of Social Sciences and Humanities (IJSSH), 1(2), 20-28.

Astawa, I. N., Mantra, I. B. N., \& Widiastuti, I. A. M. S. (2017). Developing Communicative English Language Tests for Tourism Vocational High School Students. International Journal of Social Sciences and Humanities (IJSSH), 1(2), 58-64.

Basak, A., \& Khanna, K. (2017). A Study on the Selection Criteria of Different Hotels of Delhi NCR in Accordance to the HR Policies and Market Trends. International Journal of Social Sciences and Humanities (IJSSH), 1(1), 27-38.

Billaiya, R., Malaiya, S., \& Parihar, K. S. (2017). Impact of Socio Economic Trends on Students in Quality Education System. International Journal of Social Sciences and Humanities (IJSSH), $1(1), 16-20$.

Black, P. Harrison, C. Lee, C. Marshall, B., and William, D. 2004. Working inside the box: Assessment for Learning in the classroom. Phi Delta Kappan. Volume 86, number 1. Pages 821.

Box, C., Skoog, G., Dabbs, J.M, 2015. A Case Study of Teacher Personal Practice Assessment Theories and Complexities of Implementing Formative Assessment. American Educational Research Journal Vol. 52, No. 5, pp. 956-983.

Cedeño, M. L. D., Arteaga, M. G. D., Pérez, A. V., \& Arteaga, M. L. D. (2017). Regulatory Framework for Renewable Energy Sources in Ecuador Case Study Province of Manabí. International Journal of Social Sciences and Humanities (IJSSH), 1(2), 29-42.

Gámez, M. R., Pérez, A. V., Será, A. S., \& Ronquillo, Z. M. (2017). Renewable Energy Sources and Local Development. International Journal of Social Sciences and Humanities (IJSSH), 1(2), 10 19.

Ghosh, C. (2017). A Study on-Evaluating Marketing Strategies Adopted by Home Appliance for Economic Development in India. International Journal of Social Sciences and Humanities (IJSSH), 1(1), 9-15.

Maba, W. (2017). Teacher's Perception on the Implementation of the Assessment Process in 2013 Curriculum. International Journal of Social Sciences and Humanities (IJSSH), 1(2), 1-9.

Maba, W., \& Mantra, I. B. N. (2017). An Analysis of Assessment Models Employed by The Indonesian Elementary School Teachers. International Journal of Social Sciences and Humanities (IJSSH), 1(1), 39-45.

McMillan, J. H., Venable, J. C., \& Varier, D. 2013. Studies of the Effect of Formative Assessment on Miles, M. B., \& Huberman, A.M. 1994. Qualitative data analysis. Thousand Oaks, CA: Sage. School

Maba, W., \& Mantra, I. B. N. (2017). An analysis of assessment models employed by the Indonesian elementary school teachers. International Journal of Social Sciences and Humanities, 1(1), 39-45.

https://doi.org/10.29332/ijssh.v1n1.38 
Mulyasa. 2013. Curriculum Development and Implementation 2013. Bandung: PT Remaja Rosdakarya Regulation of Minister of Education and Culture No. 66 the year 2013.

Nespor, J. 1987. The Role of Beliefs in The Practice of Teaching. Journal of Curriculum Studies, 19(4), 317-328.

Newton, P. E. 2007. Clarifying the Purposes of Educational Assessment. Assessment in Education: Principle Policy \& Practice, 14 (2), 149-170.

Rahman, N. F., Babu, R \& Ashrafuzzaman, M. 2011. Assessment and Feedback Practices in the English Language Classroom. Journal of Nelta, Vol. 16 No. 1-2

Shepard, L. A. 2005. Linking Formative Assessment to Scaffolding. Educational Leadership, 63, 66-70.

Sri Widiastuti, I.A.Md. 2016. EFL Teachers' Beliefs and Practices of Formative Assessment to Promote Active Learning. The ASIAN EFL Journal. Volume 3.

Sri Widiastuti, I.A.Md. 2017. Teachers' Understanding of Formative Assessment. Jurnal Bahasa dan Seni. Vol 45, No 1 Juni 2017.

Student Achievement: So Much More is Needed. Practical Assessment, Research \& Evaluation, 18 (2), 1-15.

Suparsa, I. N., Mantra, I. B. N., \& Widiastuti, I. A. M. S. (2017). Developing Learning Methods of Indonesian as a Foreign Language. International Journal of Social Sciences and Humanities (IJSSH), 1(2), 51-57.

Suryasa, I. W., Prayoga, I. G. P. A., \& Werdistira, I. W. A. (2017). An Analysis of Students' Motivation Toward English Learning As Second Language Among Students In Pritchard English Academy (PEACE). International Journal of Social Sciences and Humanities (IJSSH), $1(2), 43-50$.

Taras, M. 2005. Assessment-Summative and Formative-Some Theoretical Reflections. British Journal of Educational Studies, 53/4, 466-478. 


\section{Biography of Authors}

\begin{tabular}{|l|l||}
\hline & $\begin{array}{l}\text { Prof. Dr. Wayan Maba is a Professor in educational psychology in the } \\
\text { Mahasaraswati University of Denpasar. He is a lecturer on diverse subjects } \\
\text { related to educational fields. He is currently teaching the students of the } \\
\text { undergraduate and postgraduate study program in Mahasaraswati } \\
\text { University and other universities in Bali. Prof. Dr. Wayan Maba has } \\
\text { conducted extensive research in Education system, curriculum, and } \\
\text { assessment and other related topics and his papers have been published } \\
\text { nationally and internationally in various reputable journals }\end{array}$ \\
\hline $\begin{array}{l}\text { Dr. Ida Bagus Nyoman Mantra, SH., S.Pd., M.Pd holds a doctoral degree } \\
\text { in Linguistics from Udayana University, a lecturer in English Education in } \\
\text { the Mahasaraswati University of Denpasar. He is teaching English } \\
\text { language teaching methods, research methodology, curriculum and } \\
\text { materials development and textbook analysis. Dr. Ida Bagus Nyoman } \\
\text { Mantra, SH., S.Pd., M.Pd has carried out several studies on language } \\
\text { education, oral tradition, and human right laws. His study focus is on } \\
\text { investigating functions, values, and meanings of Balinese oral tradition. } \\
\text { His articles have been published in several national education and } \\
\text { linguistics journals. }\end{array}$ \\
\hline
\end{tabular}

Maba, W., \& Mantra, I. B. N. (2017). An analysis of assessment models employed by the Indonesian elementary school teachers. International Journal of Social Sciences and Humanities, 1(1), 39-45. 